\title{
Conditioned Media of Human Umbilical Cord Blood Mesenchymal Stem Cell-derived Secretome Induced Apoptosis and Inhibited Growth of HeLa Cells
}

\author{
Ferry Sandra ${ }^{1,2,3 *}$, Janti Sudiono ${ }^{4}$, Elina Ardiani Sidharta ${ }^{5}$, Elisabeth Pricilia Sunata ${ }^{5}$, \\ Dea Jane Sungkono ${ }^{5}$, Yanni Dirgantara ${ }^{6}$, Angliana Chouw ${ }^{6}$
}

\begin{abstract}
${ }^{1}$ Department of Biochemistry and Molecular Biology, Faculty of Dentistry, Trisakti University, Jl. Kyai Tapa No.260, Jakarta, Indonesia ${ }^{2}$ BioCORE Laboratory, Faculty of Dentistry, Trisakti University, Jl. Kyai Tapa No.260, Jakarta, Indonesia ${ }^{3}$ Prodia Clinical Laboratory, Prodia Tower, J1. Kramat Raya No.150, Jakarta, Indonesia ${ }^{4}$ Department of Oral Pathology, Faculty of Dentistry, Trisakti University, Jl. Kyai Tapa No.260, Jakarta, Indonesia ${ }^{5}$ Faculty of Dentistry, Trisakti University, Jl. Kyai Tapa No.260, Jakarta, Indonesia ${ }^{6}$ PT. Prodia Stemcell Indonesia, Jl. Kramat 7 No.11, Jakarta, Indonesia *Corresponding author. E-mail: ferrysandra@gmail.com
\end{abstract}

\section{Abstract}

$\mathrm{B}$ ACKGROUND: Secreted factors contained in conditioned media $(\mathrm{CM})$ of human umbilical cord blood mesenchymal stem cells (hUCB-MSCs) known as secretome, was suspected to have important roles in regulating cells. This study was conducted to investigate the role of CM-hUCB-MSCs-derived secretome in apoptosis and growth of HeLa cells.

METHODS: HeLa cells were treated with secretome in various concentrations $(0,0.2,2$ and $20 \%)$ for 24 and 48 hours. Trypan blue exclusion assay was performed to detect cell viablity. Meanwhile sub-G1 apoptotic assay was performed to detect apoptotic cells. The transition of mitochondrial transmembrane potential (TMP), which occurs in the apoptotic process, was analyzed by mitochondrial membrane potential $(\Delta \Psi \mathrm{M})$ assay. Both sub-G1 and $\triangle \Psi \mathrm{M}$ assays were performed using FACSCanto flow cytometer. Statistical analyses were conducted using IBM SPSS Statistics to detect significance level at $\mathrm{p}<0.05$.

RESULTS: Secretome significantly induced cell death starting at concentration of $0.2 \%$ within a 24 -hour period $(p<0.05)$. Secretome significantly induced cell death in concentration and time dependent manner $(p<0.05)$. The cell death was then confirmed as apoptosis through sub-G1 analysis. Due to the underlying apoptotic mechanism, we found distinct decrease of TMP, indicating an increase in mitochondrial membrane permeability of HeLa cells. In

Abstrak

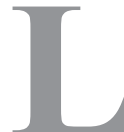

ATAR BELAKANG: Sekretom merupakan berbagai faktor yang disekresikan oleh sel punca mesenkimal darah tali pusat yang terkandung dalam media yang dikondisikan. Sekretom diperkirakan memiliki peran penting dalam meregulasi sel. Studi berikut dilakukan untuk mengetahui peran sekretom dalam induksi apoptosis dan hambatan pertumbuhan pada sel HeLa.

METODE: Sel HeLa diberi perlakuan dengan sekretom pada konsentrasi yang bervariasi (0, 0,2, 2 dan 20\%) selama 24 dan 48 jam. Pemeriksaan trypan blue exclusion dilakukan untuk mendeteksi viabilitas sel. Sedangkan pemeriksaan sub-G1 dilakukan untuk mendeteksi sel yang mengalami apoptosis. Transition of mitochondrial transmembrane potential (TMP) dapat terjadi pada proses apoptosis yang dapat dianalisis dengan pemeriksaan mitochondrial membrane potential $(\triangle \Psi \mathrm{M})$. Pemeriksaan sub-G1 dan $\triangle \Psi \mathrm{M}$ dilakukan menggunakan alat FACSCanto flow cytometer. Analisis statistik dilakukan dengan mendeteksi level signifikan pada $\mathrm{p}<0,05$.

HASIL: Sekretom secara signifikan $(\mathrm{p}<0,05)$ menginduksi kematian sel berawal dari konsentrasi $0,2 \%$ dalam waktu 24 jam. Sekretom secara signifikan $(p<0,05)$ menginduksi kematian sel bergantung pada konsentrasi sekretom dan waktu perlakukan. Kematian sel tersebut merupakan proses apoptosis yang dikonfirmasikan dengan pemeriksaan sub-G1. Terkait mekanisme apoptosis yang ditimbulkan, 
addition, we found that HeLa cell growth was inhibited partially by secretome.

CONCLUSION: Taken together, we conclude that CMhUCB-MSCs-derived secretome significantly induced apoptosis of HeLa cells in a concentration and time dependent manner through mitochondrial apoptotic pathway. The secretome might also play important role in inhibiting HeLa cell growth.

KEYWORDS: umbilical cord blood, mesenchymal stem cell, secretome, apoptosis, growth, cancer

Indones Biomed J. 2014; 6(1): 57-62

\section{Introduction}

Mesenchymal stem cells (MSCs) have been defined as a major type of non-haematopoietic cells that display a potential to self-renew and to undergo multilineage differentiation due to the multipotent capacity and are thus an attractive source of stem cells for tissue engineering.(1) Based on the number of cells, accessibility and research reports, there are three MSCs main sources for clinical use: bone marrow, adipose tissue and umbilical cord blood (UCB).(2) MSCs derived from these sources exhibited minimum MSCs criteria according to the International Society for Cell Therapy (ISCT) which are: 1) adherence to plastic in standard culture conditions; 2) specific surface antigen expression, i.e. positive expression $(\geq 95 \%$ positive) of cluster of differentiation (CD)105, CD73, CD90 expressions, and lack expression $(\leq 2 \%$ positive) of CD45, CD34, CD14 or CD11b, CD79a or CD19 and human leukocyte antigen (HLA)-DR; 3 ) the ability to differentiate into osteoblasts, adipocytes, chondroblasts under standard in vitro differentiating conditions. $(2,3)$

Human UCB (hUCB) is considered as the most suitable source of MSCs because it has less ethical complications, and easy to isolate via non-invasive methods.(1) It has been reported that neonatal MSCs have lower immunogenicity and stronger immunosuppressive capacity which indicates that they are more suitable for therapeutic approaches.(1) MSCs participate in the structural and functional maintenance of connective tissues under normal homeostasis and also act as trophic mediators during tissue repair, generating bioactive molecules that help in tissue regeneration following injury. $(4,5)$ kami menemukan adanya penurunan TMP yang berarti terjadinya peningkatan permeabilitas membran mitokondria pada sel HeLa. Selain itu, pertumbuhan sel HeLa juga mengalami inhibisi secara parsial oleh sekretom.

KESIMPULAN: Sekretom yang disekresikan oleh sel punca mesenkimal darah tali pusat yang terkandung dalam media yang dikondisikan ini, secara signifikan menginduksi apoptosis sel HeLa dan berkorelasi dengan konsentrasi sekretom dan lama perlakuan. Apoptosis yang ditimbulkan merupakan jalur apoptosis mitokondria. Sekretom juga berperan dalam menghambat pertumbuhan sel HeLa.

KATA KUNCI: darah tali pusat, sel punca mesenkimal, sekretom, apoptosis, pertumbuhan, kanker

More recently, MSCs have become a topic of great focus in relation to the cancer. Growing evidence suggests that MSCs home to not just injured tissues but tumors, where they have an important role in affecting the behavior of tumor cells.(6) MSCs are known to secrete a broad panel of proteins including growth factors, chemokines and cytokines, which are called secretome.(7) It has been reported that secretome contained in conditioned media (CM) of MSCs promotes apoptosis and autophagy of cancer cells.(8) Tumor Necrosis Factor (TNF)- $\alpha$, Transforming Growth Factor (TGF)- $\beta$, and Interferon (IFN)- $\gamma$ are known to influence cell cycle regulation, as well as induce growth attenuation and apoptosis in cancer cells.(8) Despite some evidences demonstrate that MSCs can suppress tumorigenesis, others show that MSCs favor tumor growth. $(9,10)$ Since the role of MSCs on tumors remains unclear, we conducted an in vitro study to investigate the effect of hUCB-MSCs on HeLa cells.

\section{Methods}

\section{Cell culture and CM of hUCB-MSCs (CM-hUCB-} MSCs)-derived secretome preparation

HeLa cells were cultured in Dulbecco's Modified Eagle Medium containing $10 \%$ fetal bovine serum, penicillin, streptomycin, and amphotericin B. Meanwhile, hUCBMSCs (3H Biomedical AB, Uppsala, Sweden) were cultured in Mesencult media (StemCell Technologies Inc., Vancouver, Canada) containing penicillin and streptomycin. Upon reaching 80\% confluency, hUCB-MSCs media was replaced with supplement-free media and incubated for 24 hours. Media was collected and centrifuged. Resulted 
supernatant was used as CM-hUCB-MSCs-derived secretome.

\section{Trypan blue exclusion assay}

Treated cells were harvested and stained with trypan blue. Cell morphology and calculation were observed using hemocytometer under an inverted light microscope. Membrane integrity of apoptotic cell can be demonstrated by the exclusion of this dye. Viable cells will appear clear whereas dead cells will appear blue.

\section{Sub-G1 analysis}

Sub-G1 analysis was performed as described previously. $(11,12)$ Treated cells were harvested and suspended in $1 \mathrm{ml}$ of hypotonic fluorochrome solution $(50 \mu \mathrm{g} / \mathrm{ml}$ propidium iodide in $0.1 \%$ sodium citrate containing $0.1 \%$ Triton $\mathrm{X}-100$ ). Cell suspensions were placed at $4^{\circ} \mathrm{C}$ in the dark, overnight before flow cytometric analysis. The propidium iodide fluorescence of individual nuclei was measured using a FACSCanto II flow cytometer (Becton Dickinson \& Co, Franklin Lakes, NJ, USA).

\section{$\Delta \Psi M$ analysis}

$\Delta \Psi \mathrm{M}$ analysis was performed as described previously. $(11,12)$ After treatment, cells were harvested and suspended in $250 \mu \mathrm{l}$ of $20 \mathrm{nM} \mathrm{3,3'-Dihexyloxacarbocyanine} \mathrm{Iodide}$ $\left(\mathrm{DiOC}_{6}\right)$ in Phosphate-Buffered Saline (PBS) and incubated in an incubator for 15 minutes. $\triangle \Psi \mathrm{M}$ was measured using a FACSCanto flow cytometer.

\section{Statistical analysis}

Statistical analyses were performed using IBM SPSS Statistics for Macintosh version 21 (SPSS IBM, Armonk, NY, USA). One way Analysis of Variance (ANOVA) was used to compare means of two or more groups. Unpaired t-test and Mann-Whitney test was used to compare two populations means. Two-way ANOVA was used to compare means of groups with more than two factors. Statistically significance is expressed as $\mathrm{p}<0.05$.

\section{Results}

\section{Secretome partially inhibited the growth and induced the apoptosis of HeLa cells}

Lower cell density of secretome-treated HeLa cells was observed (Figure 1A-D). The lower HeLa cells density was observed started from treatment of $0.2 \%$ secretome (Figure 1B). Meanwhile, 20\% secretome-treated HeLa cells had the lowest cell density. We also found that cells treated for 48 hours have lower density compared with 24 hours. These results showed that HeLa cells density was regulated by secretome in concentration and time dependent manner.

When we performed cell counting, HeLa cells treated with higher concentration and longer treatment period had lower total cell population. This result suggested that the growth of HeLa cells was inhibited partially by secretome in a concentration and time dependent manner. By MannWhitney test, we found significant differences between total population of the cells treated with $0 \%$ secretome and the ones treated with $0.2 \%, 2 \%, 20 \%$ secretome in the period of 24 hours ( $p=0.02 ; p=0.001 ; p=0.001$ respectively). We also found significant differences between total population of the cells treated with $0 \%$ secretome and the ones treated with $0.2 \%, 2 \%, 20 \%$ secretome in the period of 48 hours

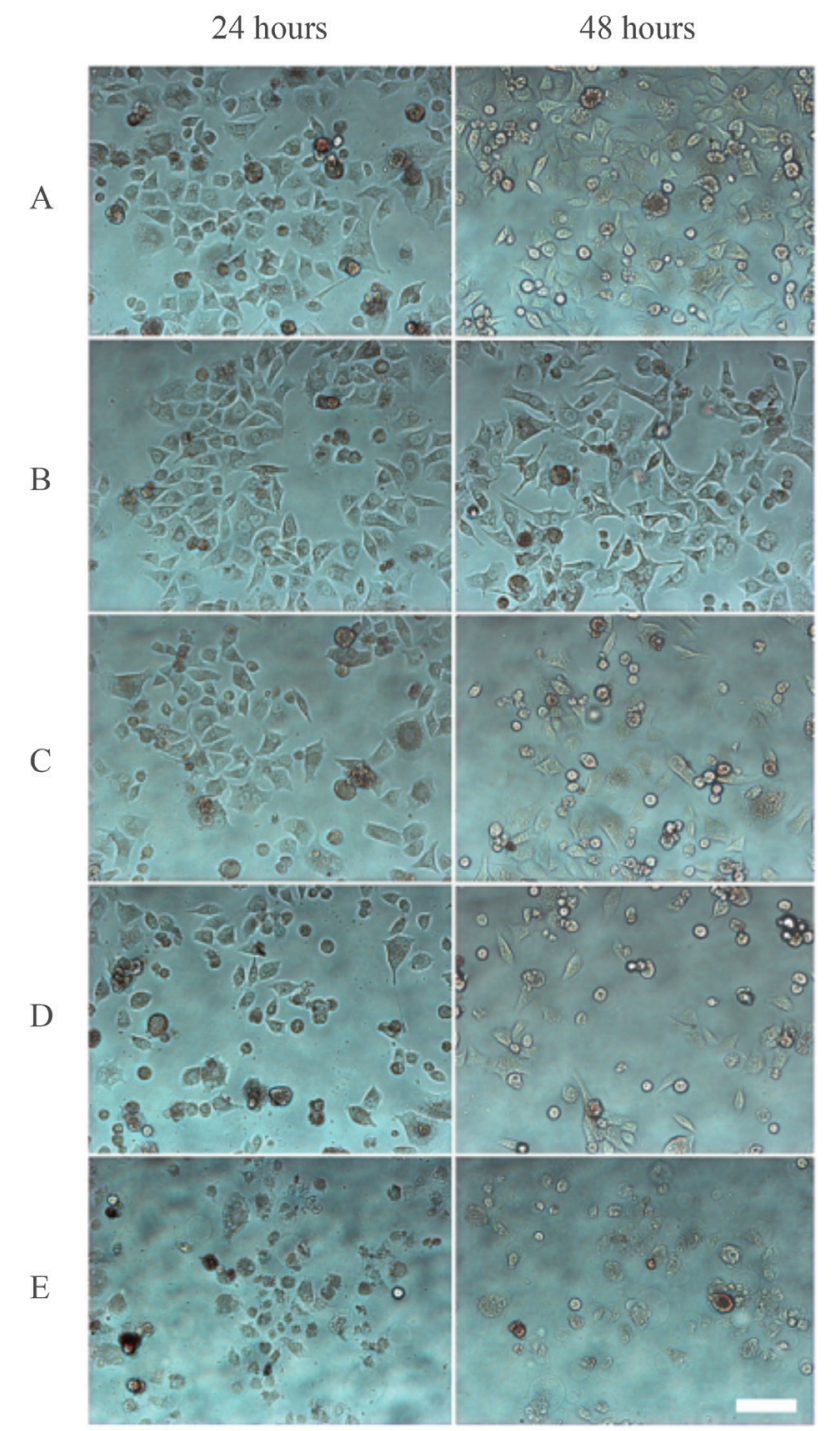

Figure 1. HeLa cells density under treatment of secretome. In 6-well culture plate, $6 \times 10^{4} \mathrm{HeLa}$ cells were seeded, starved and treated with 0 (A), 0.2 (B), 2 (C) and 20\% (D) for 24 and 48 hours. $\mathrm{H}_{2} \mathrm{O}_{2}$ (E) was used as positive control for apoptosis inducing activity. HeLa cells were observed and captured under an inverted light microscope. White bar: $100 \mu \mathrm{m}$. 
Table 1. HeLa cells viability under treatment of CM-hUCBMSCs-derived secretome for 24 hours.

\begin{tabular}{ccccc}
\hline \multirow{2}{*}{ Viability } & \multicolumn{4}{c}{ CM-hUCB-MSCs-derived Secretome } \\
\cline { 2 - 5 } & $\mathbf{0} \%$ & $\mathbf{0 . 2 0} \%$ & $\mathbf{2 \%}$ & $\mathbf{2 0} \%$ \\
\hline Viable & $147,188 \pm 19,385$ & $115,938 \pm 13,156$ & $93,125 \pm 9,977$ & $83,750 \pm 9,354$ \\
$($ Mean \pm SD) & & & & \\
Dead & $11,563 \pm 2,969$ & $20,313 \pm 2,814$ & $24,063 \pm 2,290$ & $25,000 \pm 1,889$ \\
(Mean \pm SD) & & & & \\
\hline Total & 158,750 & $136,250^{*}$ & $117,188^{*}$ & $108,750^{*}$ \\
\hline
\end{tabular}

*: Mann-Whitney test, $\mathrm{p}<0.05$; total population of the cells treated with $0 \%$ secretome was compared with the ones treated with 0.2 , 2 and $20 \%$ secretome.

Table 2. HeLa cells viability under treatment of CM-hUCBMSCs-derived secretome for 48 hours.

\begin{tabular}{ccccc}
\hline \multirow{2}{*}{ Viability } & \multicolumn{4}{c}{ CM-hUCB-MSCs-derived Secretome } \\
\cline { 2 - 5 } & $\mathbf{0 \%}$ & $\mathbf{0 . 2 0} \%$ & $\mathbf{2 \%}$ & $\mathbf{2 0 \%}$ \\
\hline Viable & $165,625 \pm 23,480$ & $115,313 \pm 8,602$ & $95,313 \pm 12,059$ & $85,625 \pm 7,989$ \\
(Mean \pm SD) & & & & \\
Dead & $11,875 \pm 1,767$ & $24,063 \pm 4,419$ & $31,563 \pm 1,860$ & $40,625 \pm 2,587$ \\
(Mean \pm SD) & & & & \\
\hline Total & 177,500 & $139,375^{*}$ & $126,875^{*}$ & $126,250^{*}$ \\
\hline
\end{tabular}

*: Unpaired t-test, $\mathrm{p}<0.05$; total population of the cells treated with $0 \%$ secretome was compared with the ones treated with $0.2,2$ and $20 \%$ secretome.

$(\mathrm{p}=0.001 ; \mathrm{p}=0.000 ; \mathrm{p}=0.000$ respectively, Unpaired $\mathrm{t}$-test $)$.

Higher trypan blue-stained dead cell number was found in the cells treated with secretome for 48 hours compared with the ones treated for 24 hours (Table 1\&2). Significant cell death difference between 24 and 48 hours
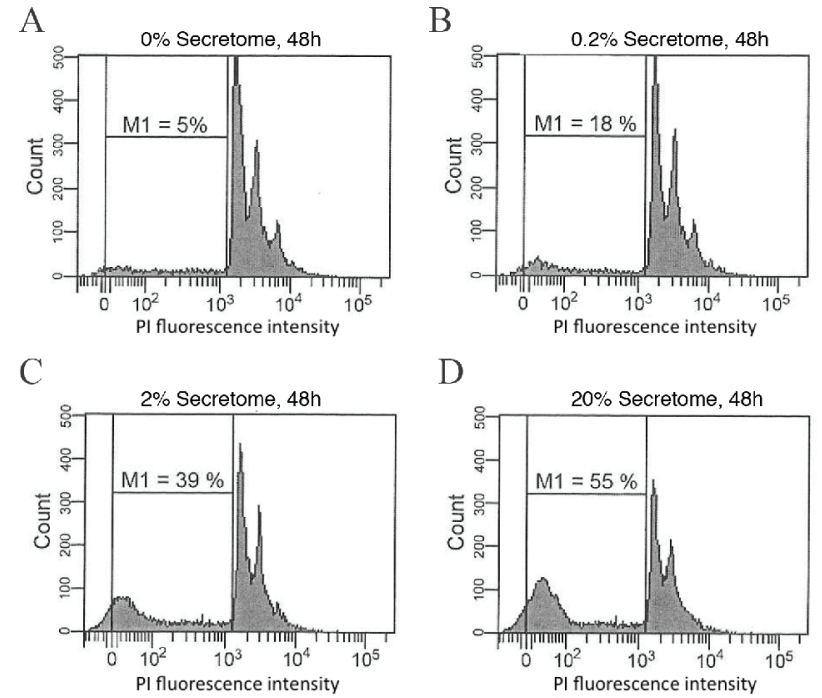

Figure 2. Flow cytometry detection of apoptotic cells. HeLa cells were seeded, starved, and treated with CM-hUCB-MSCsderived secretome at 0 (A), 0.2 (B), 2 (C), and 20\% (D) for 48 hours. Apoptosis quantification was performed according to Sub-G1 analysis as described in "Material and Methods". PI: Propidium Iodide; M1: sub-G1 area. was obtained for the cells treated with $0.2 \%$ secretome. Similar results were also found for the cells treated with $2 \%$ or $20 \%$ secretome ( $<<0.05$, Unpaired t-test). Secretomecaused cell death was significantly different between concentrations in both 24 and 48 hours treatment $(\mathrm{p}<0.05$, ANOVA). The post-hoc analysis showed that secretome significantly induced cell death starting at concentration of $0.2 \%$ within a 24 -hour period $(\mathrm{p}<0.05)$. Two-way ANOVA analysis results showed that secretome induced cell death in concentration and time dependent manner $(\mathrm{p}<0.05)$.

By performing Sub-G1 analysis, the secretome-caused cell death was confirmed as apoptosis. The results showed an increase of M1 area, indicating an increase of apoptotic cells along with the increase of secretome concentrations (Figure 2). The highest percentage of apoptotic cells at 55\% was found at the treatment of $20 \%$ secretome for 48 hours. The secretome-caused apoptosis in concentration dependent manner is consistent with the result of cell counting with trypan blue exclusion assay.
24 hours

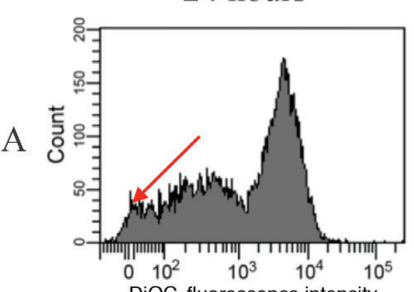

$\mathrm{DiOC}_{6}$ fluorescence intensity

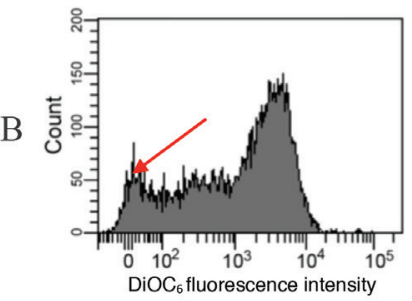

$\mathrm{C}$

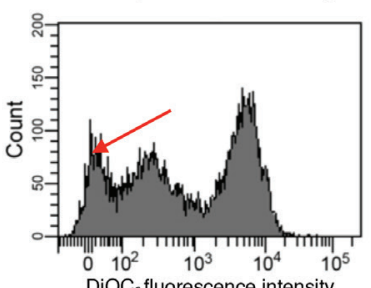

D

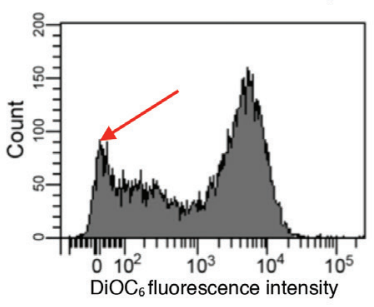

48 hours

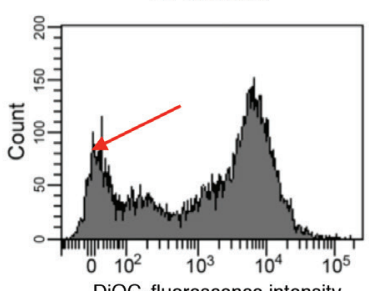

$\mathrm{DiOC}_{6}$ fluorescence intensity
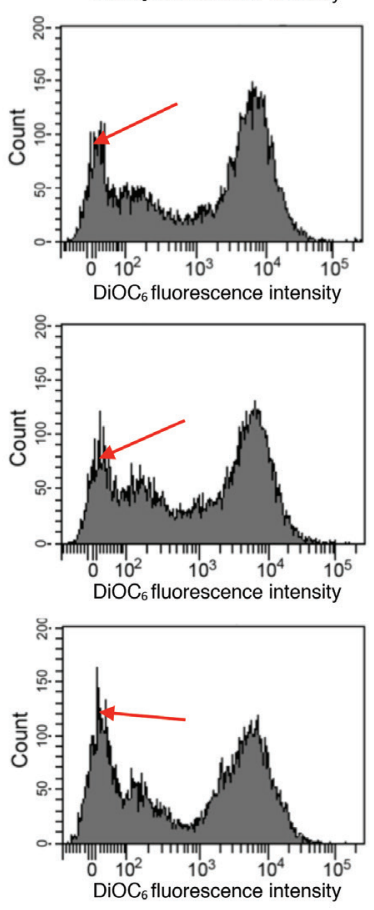

Figure 3. HeLa cells mitochondrial membrane permeabilization. HeLa cells were seeded, starved, and treated with CM-hUCBMSCs-derived secretome at 0 (A), 0.2 (B), 2 (C), and 20\% (D) for 24 and 48 hours. TMP was assayed by $\triangle \Psi M$ analysis as described in "Material and Methods". Red arrow shows the amount of HeLa cells with TMP loss. 
Transition of mitochondrial transmembrane potential (TMP) loss of HeLa cells treated with CM-hUCB-MSCsderived secretome

To study the mechanism involved in secretome-induced HeLa cells apoptosis, TMP was investigated by $\Delta \Psi \mathrm{M}$ analysis. In mitochondrial apoptotic pathway, loss of TMP is largely due to the opening of mitochondrial permeability transition pores, reflected by the loss of $\mathrm{DiOC}_{6}$ fluorescence. Higher cell number with low TMP was observed in HeLa cells treated with $20 \%$ secretome for 48 hours compared with the one treated for 24 hours (Figure 3D). These results proved that secretome reduced HeLa cells TMP in concentration and time dependent manner.

\section{Discussion}

It has been reported that MSCs have the ability to inhibit proliferation and induce apoptosis of cancer cells. Recent study reported that CM derived from human Wharton's jelly stem cells promotes cancer cells apoptosis and autophagy. (13) Meanwhile another study reported that $\mathrm{CM}$ of bone marrow MSCs promotes the growth of breast cancer cells in mouse.(14) The controversy that MSCs exhibit pro- or anti-proliferative effects on growth of tumor cells might be interpreted by the malignant cell type being studied; the interaction fashion between MSCs and the tumor cells; and the cell number of MSCs used. In addition, different MSCs sources might be associated with different effects on the tumor growth.(10) Although MSCs derived from different sources share many characteristics features, they differ in many aspects of gene expression profile and physiology.(15)

In this study, cell density of HeLa cells population was lower when treated at higher concentration of secretome. We also found higher cell density in 24-hour treatment period, compared with the one treated for 48 hours. By trypan blue exclusion assay, we found the lower cell density was due to lower cell population growth and higher cell death. Cell death was then confirmed as apoptosis according to Sub-G1 results. Our results showed that, besides having the potential to partially inhibit cell growth, CM-hUCB-MSCsderived secretome also has the ability to induce HeLa cells apoptosis in concentration and time dependent manner.

The reduction of cells TMP indicating permeabilized mitochondrial membrane (16), was observed in secretometreated HeLa cells. We found that cells TMP was reduced when treated with higher concentration and longer treatment period of secretome. These results suggested that CM-hUCB-MSCs-derived secretome increased the number of HeLa cells in the initiation phase of apoptosis through mitochondrial pathway in concentration and time dependent manner.

The crucial event in mitochondrial apoptotic pathway is the mitochondrial outer-membrane permeabilization which releases numerous pro-apoptotic proteins into the cytosol. $(11,12,17)$ Pro-apoptotic protein such as cytochrome-c will activate the caspase-dependent mitochondrial apoptotic pathway by its binding with Apoptotic protease-activating factor 1 (Apaf-1) as well as procaspase-9, forming an apoptosome. $(16,18)$ Apoptosome cause the activation of caspase-9, which subsequently activates the caspase-3 through proteolytic processing.(18-20)

It is known that hUCB-MSCs secrete various growth factors, inflammatory cytokines and chemokines, and express receptors and/or counter-receptors both for cell-cell and cell-matrix intervention.(21) Some research reported that several cytokines and chemokines from MSCs such as C-X-C motif chemokine 10 (CXCL10), IFN- $\gamma$-inducible protein (IP)-10, interleukin (IL)-6, IL-8, IFN-1 $\beta$, and TNF- $\alpha$ played an important role in inhibiting proliferation of cancer cells in vitro.(22) Other reports have stated that TNF- $\alpha$, TGF- $\beta$ and IFN- $\gamma$ affect cell cycle regulation in cancer cells by causing cell growth attenuation and induce apoptosis. (10) Thus, it is likely that secretome induced apoptosis and inhibited growth of HeLa cells.

\section{Conclusion}

Taken together, we conclude that CM-hUCB-MSCsderived secretome significantly induced apoptosis of HeLa cells in a concentration and time dependent manner through mitochondrial apoptotic pathway. CM-hUCBMSCs-derived secretome might also play important role in inhibiting HeLa cell growth. Further investigations should be pursued to confirm the presence of mitochondrial proapoptotic and growth inhibiting factors in secretome.

\section{Acknowledgements}

The authors thank Faculty of Dentistry Trisakti University Indonesia, and PT. Prodia StemCell Indonesia for invaluable support in this study.

\section{References}

1. Jin HJ, Bae YK, Kim M, Kwon SJ, Jeon HB, Choi SJ, et al Comparative analysis of human mesenchymal stem cells from bone marrow, adipose tissue, and umbilical cord blood as sources of cell therapy. Int J Mol Sci. 2013; 14: 17986-8001. 
2. Divya MS, Roshin GE, Divya TS, Rasheed VA, Santhoshkumar TR, Elizabeth KE, et al. Umbilical cord blood-derived mesenchymal stem cells consist of a unique population of progenitors coexpressing mesenchymal stem cell and neuronal markers capable of instantaneous neuronal differentiation. Stem Cell Res Ther. 2012; 3: 57. doi: 10.1186/scrt148.

3. Dominici M, Le Blanc K, Mueller I, Slaper-Cortenbach I, Marini FC, Krause DS, et al. Minimal criteria for defining multipotent mesenchymal stromal cells: The International Society for Cellular Therapy position statement. Cytotherapy. 2006; 8: 315-7.

4. Aini N, Setiawan B, Sandra F. Karakterisitik biologis dan diferensiasi stem cell: fokus pada mesenchymal stem cell. CDK. 2008; 35: 64-7.

5. Can A. Adult and Embryonic Stem Cells. 1st ed. Ottawa: Springer; 2012.

6. Zimmerlin L, Park TS, Zambidis ET, Donnenberg VS, Donnenberg AD. Mesenchymal stem cell secretome and regenerative therapy after cancer. Biochimie. 2013; 95: 2235-45.

7. Cuiffo BG, Karnoub AE. Mesenchymal stem cells in tumor development emerging roles and concepts. Cell Adh Migr. 2012; 6: 220-30.

8. Gauthaman K, Yee FC, Cheyyatraivendran S, Biswas A, Choolani M, Bongso A. Human umbilical cord Wharton's jelly stem cell (hWJSC) extracts inhibit cancer cell growth in vitro. J Cell Biochem. 2012; 113: 2027-39.

9. Zhang T, Lee YW, Rui YF, Cheng TY, Jiang XH, Li G. Bone marrowderived mesenchymal stem cells promote growth and angiogenesis of breast and prostate tumors. Stem Cell Res Ther. 2013; 4: 70. doi: $10.1186 /$ scrt221.

10. Long X, Matsumoto R, Yang P, Uemura T. Effect of human mesenchymal stem cells on the growth of HepG2 and Hela cells. Cell Struct Funct. 2013; 38: 109-21.

11. Sandra F, Hendarmin L, Nakao Y, Nakamura N, Nakamura S. TRAIL cleaves caspase- $8,-9$ and -3 of AM-1 cells: a possible pathway for TRAIL to induce apoptosis in ameloblastoma. Tumour Biol. 2005; 26: 258-64.

12. Arung ET, Wicaksono BD, Handoko YA, Kusuma IW, Shimizu K, Yulia D, et al. Cytotoxic effect of artocarpin on T47D cells. J Nat Med. 2010; 64: 423-9.

13. Chan JK, Lam PY. Human mesenchymal stem cells and their paracrine factors for the treatment of brain tumors. Cancer Gene Ther. 2013; 20(10): 539-43.

14. Zhang T, Lee YW, Rui YF, Cheng TY, Jiang XH, Li G. Bone marrowderived mesenchymal stem cells promote growth and angiogenesis of breast and prostate tumors. Stem Cell Res Ther. 2013; 4: 70. doi: $10.1186 /$ scrt221.

15. Akimoto K, Kimura K, Nagano M, Takano S, To'a Salazar G, Yamashita $\mathrm{T}$, et al. Umbilical cord blood-derived mesenchymal stem cells inhibit, but adipose tissue-derived mesenchymal stem cells promote, glioblastoma multiforme proliferation. Stem Cells Dev. 2013; 22: 1370-86.

16. Sandra F, Matsuda M, Yoshida H, Hirata M. Inositol hexakisphosphate blocks tumor cell growth by activating apoptotic machinery as well as by inhibiting the Akt/NFKB-mediated cell survival pathway. Carcinogenesis. 2002; 23: 2031-41.

17. Lis R, Touboul C, Halabi NM, Madduri AS, Querleu D, Mezey J, et al. Mesenchymal cell interaction with ovarian cancer cells induces a background dependent pro-metastatic transcriptomic profile. J Transl Med. 2014; 12: 59. doi: 10.1186/1479-5876-12-59.

18. Sandra F, Degli Esposti M, Ndebele K, Gona P, Knight D, Rosenquist M, Khosravi-Far R. Tumor Necrosis Factor-Related ApoptosisInducing Ligand Alters Mitochondrial Membrane Lipids. Cancer Res. 2005; 65: 8286-97.
19. Vermes I, Haanen C, Reutelingsperger C. Flow cytometry of apoptotic ell death. J Immunol Methods. 2000; 243: 167-90.

20. Hendarmin L, Kawano S, Daigo Yoshiga D, Sandra F, Mitsuyasu T, Nakao Y, et al. An anti-apoptotic role of NF- $\mathrm{kB}$ in TNF $\alpha$-induced apoptosis in an ameloblastoma cell line. Oral Sci Int. 2008; 5: 96103.

21. Yang SH, Wu CC, Shih TT, Sun YH, Lin FH. In vitro study on interaction between human nucleus pulposus cells and mesenchymal stem cells through paracrine stimulation. Spine (Phila Pa 1976). 2008; 33: 1951-7.

22. Tomchuck SL, Zwezdaryk KJ, Coffelt SB, Waterman RS, Danka ES, Scandurro AB. Toll-like receptors on human mesenchymal stem cells drive their migration and immunomodulating responses. Stem Cells. 2008; 26: 99-107. 